\title{
The Two Faces of Foreign Management Capabilities: \\ FDI and Productive Efficiency in the UK Retail Sector
}

\author{
Xiaolan $\mathrm{Fu}$ \\ University of Oxford \\ Christian Helmers \\ LSE \\ Jing Zhang \\ University of Nottingham
}

\begin{abstract}
We investigate the impact of management capabilities of foreign firms on the capabilities and performance of domestic firms using survey data on the UK retail sector. On average, foreign-owned retail firms achieve higher management capability scores and are more productive than domestic firms. Our results suggest two faces of foreign management capabilities. On the one hand, capabilities that can be codified, for example human resource management capabilities, generate some positive spillovers on the relevant management capabilities of local firms. On the other hand, dimensions of capabilities that are more tacit and highly competitive exert a negative competitive effect on domestic firms' own management capabilities. While the overall management capabilities of domestic firms are found to have a significantly positive effect on their own productive efficiency, we find no evidence of a direct efficiency effect of foreign management capabilities on local firms.
\end{abstract}

Key Words: FDI, managerial capabilities, competition, spillovers, productivity, retail sector 


\section{Introduction}

Management capabilities are a key determinant of the competitive advantage of firms (Teece and Pisano, 1994) and a major source of ownership advantage of multinational enterprises (MNE) (Dunning, 1988; Cantwell, 1991). However, although there is a substantial literature on the impact of foreign direct investment (FDI) on local firms, most of the literature focuses on research and development (R\&D) and technological capabilities. Research exploring the managerial knowledge spillovers is rare, especially for the service sector, where management capabilities are likely to play an important role (Bloom and van Reenen, 2007, 2010).

The share in GDP accounted for by the service sector in industrialized countries has been growing steadily over the past four decades and it now accounts for around 70 percent of value added (including public administration, health and education services) in most OECD countries (Wölfl, 2005). In the UK, the service industry represents by far the most important sector. Excluding public administration, health and education services, it accounted for more than half of total gross value added in 2005. Measuring economic importance by employment, the service sector, again net of public administration, health and education services, corresponded to nearly half of total employment in the UK by the end of 2009. ${ }^{1}$ However, the relatively larger share in employment accounted for by the service sector is paired with lower productivity relative to the manufacturing sector (Wölfl, 2005; Griffith, et al., 2004). Griffith and Harmgart (2005) suggest that productivity in the retail sector in the UK lags considerably behind other large European countries and the US. Considering the enormous effort that has been devoted in the literature to understanding performance of manufacturing firms, further work targeted at understanding firm performance in the UK service sector promises to be particularly instructive.

Important issues in the discussion of firm performance in the manufacturing sector evolve around the presence of foreign firms and their effect on domestic firm performance through the generation of interfirm spillovers and competition effects. Yet, such analysis is almost absent from the literature on the service and in particular the retail sector with a few exceptions (see for example Griffith et al., 2004; Miozzo and Grimshaw, 2008; Hamida and Gugler, 2009; Fortanier and van Wijk, 2010; and Añon-Higon and Vasilakos, 2008). These existing studies provide evidence on the impact of FDI in the service sector on local firms through training and linkages in the supply chain. Yet there is still a substantial lack of empirical evidence on the impact of FDI in the services and in particular the retail sector. Although many studies suggest managerial knowledge spillovers as a channel for FDI to affect domestic firm performance, direct empirical evidence is scarce. An exception is Fu (2009) who explores managerial knowledge spillovers from FDI in terms of dissemination of modern management practices. Also, in light of evidence such as Buckley et al. (2007b) who point out differences in the impact of FDI on local firms

\footnotetext{
${ }^{1}$ UK Office National Statistics.
} 
across industries according to their labor intensity, findings for the service sector may differ substantially from what has been found for the manufacturing sector.

In this paper, we examine the impact of foreign management capabilities on local firms' own management capabilities and productivity using comprehensive survey data of domestic and foreign firms' management capabilities in the UK retail sector. This paper contributes to the literature on FDI spillovers as the first empirical study investigating specifically the impact of foreign managerial capabilities on the performance of local firms in the service sector. Our findings suggest that foreign management capabilities have two faces with respect to their impact on local firms. On the one hand, capabilities that can be codified, for example human resource management capabilities, generate some spillovers on the relevant management capabilities of local firms. On the other hand, dimensions of capabilities that are more tacit and highly competitive exert a negative competitive effect on domestic firms' own management capabilities. Moreover, we do not find any evidence in favor of a robust link between foreign management capabilities and domestic firm performance. Nevertheless, we confirm previous findings that foreign-owned firms have on average higher productivity levels than domestic firms and establish a positive association between a firm's own managerial capability and its efficiency.

In Section II, we discuss the existing related literature and the theoretical underpinnings of our empirical investigation; Section III describes our data set; Section IV outlines the methodology adopted to carry out our empirical analysis. Section V provides a summary of the results and Section VI concludes.

\section{Literature review}

\section{The impact of FDI in the services sector}

Foreign direct investment, as a bundle of managerial and technological knowledge and financial investment, is likely to impact on local firms through knowledge transfer and competition effects (Caves, 1974; Aitken and Harrison, 1999; Buckley et al., 2002, 2007a). ${ }^{2}$ These effects are likely to differ across industries according to industry-specific characteristics (Buckley et al., 2007b). While the literature on the effect of FDI in the services sector is embryonic, there are a number of notable exceptions. For example, Hamida and Gugler (2009) analyze spillovers in both the manufacturing sector and services/construction using data from the Swiss innovation survey. They find that the size and extent of spillovers from FDI vary according to the level of the absorptive capacity of the domestic companies. While the effect of spillovers, measured as sales by foreign-invested firms, on productivity is positive in the manufacturing sector as well as in services/construction, the beneficial effect is smaller in services/construction.

\footnotetext{
${ }^{2}$ Empirical evidence on the impact of MNEs on domestic firms is mixed. See Blomstrom and Kokko (1998) and Görg and Strobl (2001) for excellent reviews.
} 
Fortanier and van Wijk (2010) analyze the impact of FDI in the hotel industry in Sub-Saharan Africa. They use a sample of 123 foreign hotels in Mozambique, Tanzania, and Ethiopia to investigate the effect of their presence on local employment. They find no evidence for positive 'skill spillovers' as foreign hotels prefer to hire well-trained employees from local hotels rather than to contribute to the improvement of local human capital via training. Using qualitative data from case studies, Miozzo and Grimshaw (2008) investigate the impact of the presence of large foreign IT service suppliers on their client firms in Argentina and Brazil through forward linkages.

In the context of the British economy, Griffith et al. (2004) explore the impact of R\&D activity by foreign-invested companies in the UK service sector and Añon-Higon and Vasilakos (2008) investigate the presence and impact of foreign firms on productivity of domestic firms in the UK retail sector. They find that foreign-invested firms are more productive than domestic retail firms; a greater foreign employment share has a positive effect on the productivity of domestic firms in the same region and same industry, which, as argued by the authors, suggests positive productivity spillovers for domestic retailers. ${ }^{3}$ Although these as well as many other studies suggest that there may be spillovers from FDI through the dissemination of organizational innovations and improved managerial practices introduced through foreign firm entry, due to the difficulty in observation and measurement of management capabilities, they are limited to suggesting managerial knowledge spillovers as a channel of transmission but unable to test this. Testing specifically the impact of foreign management capabilities is rendered even more difficult because management capabilities include not only codified practices, but also intangible, tacit and often unique abilities/competences that enable a firm to identify, expand and exploit business opportunities (Carlsson and Eliasson, 1994). The latter capabilities are particularly hard to quantify.

\section{Management capabilities and competitive advantage}

Dynamic capabilities, as defined by Teece and Pisano (1994), emphasize the key role of strategic management in appropriately adapting, integrating and re-configuring internal and external organization skills, resources, and functional competences towards a changing environment. Distinctive firm-level capabilities include processes, positions, and paths. Processes in this context refer to the way things are done in the firm, or what might be referred to as its `routines’, patterns or current practices and learning. Positions refer to the current endowment of technology and intellectual property as well as the customer base and upstream relations with suppliers of a firm. A firm's processes and positions collectively encompass its capabilities or competences. They are major sources of a firm's competitive advantage.

\footnotetext{
${ }^{3}$ In the empirical productivity spillovers literature, knowledge and competitive advantage of FDI is often measured by the average productivity of foreign firms in the same industry or region, although there is also research using foreign employment, output or asset share in the industry or region. The latter, however, is less precise and may embed a possible association between larger and more attractive markets and the greater presence of foreign investment.
} 
Management capabilities are unique capabilities of an organization, firstly, to articulate a strategic vision and communicate it to the entire organization, providing its members with power to carry it out (Lado and Wilson, 1994; Wesley and Mintzberg, 1989) and secondly, to foster a beneficial organizationenvironment relationship (Hambrick and Mason 1984; Tushman and Romanelli, 1985). They have been found to play a significant role in explaining a firm's competitiveness (Molina et al., 2004).

Replication and imitation are important issues related to capabilities. Distinctive organizational capabilities can provide a competitive advantage and generate rents if they are based on a collection of routines, skills and complementary assets that are difficult to imitate. They may lose their value if they can be readily replicated or emulated by competitors. Capabilities and performance are also context-dependent (Teece, 1976). Many organizational routines are quite tacit in nature (Nelson and Winter, 1982). Therefore, capabilities of particular firms may be very hard to replicate (Teece and Pisano, 1994). Capabilities cannot be replicated immediately through simply entering a market and piecing parts together overnight. Replication and transfer of capabilities are often impossible without the transfer of people. Moreover, replication takes time. However, there are still situations where replication of capabilities may bring about value. First, to the extent that the capabilities in question are relevant to customer needs elsewhere, replication can confer value. Moreover, the ability to replicate also indicates that the firm has the foundations in place for learning and improvement. Finally, some capabilities are reflected in firms' adoption of various codifiable management practices and routines. These elements of capabilities may be replicated through demonstration and imitation subject to the presence of necessary absorptive capacities. Using establishment-level panel data from the UK, Fu (2009) find that MNEs have adopted more advanced management practices than local firms in most areas of firm management. These advanced management practices have diffused from MNEs to local firms and contribute to higher productivity in local firms.

\section{The impact of foreign management capabilities in the services sector}

The location-bound nature of retailing suggests that direct investment in foreign countries will be the major form of international expansion in the retail sector (Wrigley, 2000). The past two decades have witnessed rapid growth of transnational retailing (Añon-Higon, et al., 2010). The previous literature suggests that multinational enterprises must have some firm-specific advantage to compensate for the higher costs of operating in a foreign country. Such advantages could be superior managerial skills or technological capabilities. For retail firms the competitive advantages lie in five main areas: superior logistics and distribution systems to reduce inventory and distribution costs; IT system operation and supply chain management; access to low-cost capital for expansion; transfer of 'best practice' knowledge; and deep human capital (including management) resources. Moreover, international operation offers its own advantages such as access to a wide range of international management experience (Wrigley 2000). 
Foreign management capabilities may have two opposite effects on domestic firms. On the one hand, management capabilities are a unique proprietary asset. As one of the major sources of the ownership advantage of multinational enterprises which is imperfectly transferable, it will cast competitive pressure on local firms. Foreign firms may exploit their superior technology and marketing power to force local competitors to reduce their output or if they attract the most talented researchers and skilled workers and compete in the markets that threaten local firms where SMEs are in particular affected (Aghion et al., 2005; Fu, 2004; UNCTAD, 2005; Aitken and Harrison, 1999). Moreover, since most capabilities are distinctive, firm-specific and imperfectly imitable, they are difficult to replicate and imitate. Therefore, managerial capability spillovers from foreign to local firms will be limited.

Finally, foreign firms are not homogeneously willing to serve as sources of spillovers. They consider not only benefits from market entry and possible spillovers from local competitors and partners but also the possible costs of knowledge leakage. Alcácer and Chung (2007) suggest that foreign firms particularly well-suited to generate positive spillovers for domestic firms may avoid locating next to domestic firms and thereby limit knowledge leakage to domestic firms. They look at location choice of first-time foreign entrants in US economic areas between 1985 and 1994 where an entrant's location choice is determined by a trade-off between the desire to maximize absorption of spillovers from academic and government research as well as competitors and to minimize knowledge leakage to other firms. This leads foreign technologically advanced firms, with greater ability to absorb more basic and less readily appropriable knowledge from academic research, to locate in economic areas with high patenting activity by universities and to avoid areas with any patenting activity by competitors. While technologically less advanced firms also locate preferably in areas with any academic patenting activity, they also favour locations within areas with stronger innovative activity by competitors. Hence, technologically less advanced firms appear to be less able to benefit from academic knowledge spillovers and at the same time less concerned with knowledge leakage. It is therefore foreign firms with less potential knowledge outflows that locate next to incumbent domestic firms. Considering the finding by Knott et al. (2008) which suggests that spillovers from more innovative firms are more important than those from technologically laggard firms, any positive spillover effect from foreign investment would be considerably weakened if technologically advanced foreign firms avoided locating nearby domestic competitors.

On the other hand, managerial capabilities include also codified managerial knowledge and practices. These replicable components of managerial capabilities spill over to local firms through the transfer of human capital at the managerial level, inter-personal contacts, movement of managerial staff, the supply chain, or intended diffusion of best practices (Dunning, 1958; Fu, 2009). Such (un)intentional knowledge transfer can take place horizontally in the same industry; it may also take place vertically between industries through the supply chain. Knowledge spillovers have also been found to be geographically 
localized (Audretsch and Feldman, 1996). Knowledge and information may flow more easily among agents located within the same geographical area because of social bonds that foster reciprocal trust and frequent face-to-face contacts (Breschi and Lissoni, 2001). Nevertheless, successful knowledge transfer requires effective linkages between foreign firms and local suppliers and customers (Fu, 2004) and sufficient absorptive capacity of local firms and organizations (Cohen and Levinthal, 1989) and the extent of the technology gap between the foreign and local firms (Buckley et al., 2007). Moreover, the compatibility of foreign management practices with local culture affects the decision of adoption and effectiveness of assimilation of foreign management practices by local firms (Fu, 2009).

Therefore, our discussion above suggests that foreign management capabilities are likely to have two faces with regard to their impact on local firms. Firstly, as a major driver of competitive advantage of firms, management capabilities of foreign firms may generate considerable competitive pressure on local firms, especially on smaller firms. Since most capabilities are distinctive, firm-specific and imperfectly imitable, we expect limited managerial capability spillovers from foreign to local firms. When competition between foreign and local firms is strong, the net effects of foreign management capabilities on domestic firms may be negative. Second, certain types of capabilities are reflected as codified knowledge and practices. They may generate positive spillover effects on domestic firms' management capabilities and efficiency.

The above discussion leads to the following hypotheses:

Hypothesis 1. Foreign management capabilities that can be codified are likely to generate positive spillovers on the domestic firms in the same industry and region.

Hypothesis 2. Foreign management capabilities that are more tacit are unlikely to generate positive spillovers and may even have negative competitive effects on domestic firms in the same industry and region.

Hypothesis 3. The net efficiency effects of foreign management capabilities on local firms are likely to be limited due to the tacit and imperfectly imitable nature of management capabilities.

\section{Data Description}

The data used for the analysis come from a firm-level survey undertaken in 2007 containing around 1000 retail companies across the UK (SIC 52). The survey was designed and overseen by researchers at the Universities of Aston, Leeds and Oxford and sponsored by the Engineering and Physical Sciences Research Council (EPSRC). It was undertaken by a business and market research agency, using telephone interviews with senior managers responsible for operations in retail organizations. The survey used a random stratified sample of retail businesses in the UK employing 10 or more people. Businesses were 
surveyed from six retail sub-sectors. ${ }^{4}$ Within these categories, approximately 7 percent of all retail businesses operating in the UK were sampled, and 1,004 complete and valid responses were obtained. As such, the survey represents the most comprehensive survey of retailers' capabilities within the UK. Interviews were conducted with senior managers who had responsibility for operations. The response rate was 29 percent. Interviewees were asked a range of questions about the management capabilities of their UK business and other factors important to business productivity (Celia, et al., 2008).

The questionnaire contains 34 questions regarding a firm's capability in a large range of management practices. The different capabilities include a firm's capabilities in (a) human resources management, (b) operations management, (c) rewards and incentives, (d) marketing, and (e) leadership and change. For all questions related to these capabilities firms indicate both, a discrete rating ranging from zero to seven and an indication of the number of years with which they operate at the indicated level of capability. Details of the survey questions of the 34 capabilities are given in Appendix 1.

In order to obtain more detailed financial information on the firms in our sample, we matched the data with the Bureau van Dijk FAME and ICC British Company Directory databases. ${ }^{5}$ Since the survey data do not contain a firm's unique identifier, i.e., its registered number, we used a matching algorithm based on firm names. As a result of the name-based matching, some firms included in the survey could not be found in FAME or ICC. Moreover, a number of firms do not report all the variables used in the specifications of our empirical model which will be discussed in detail in Section IV. Since we use the maximum amount of available data for each specification, the sample size differs between the managerial and productivity spillover regressions. Hence, the sample used in the managerial capability regressions consists of 807 companies (757 domestic and 50 foreign firms). Because the data requirements are more stringent in the case of productivity analysis, the sample size falls further to 439 firms (389 domestic and 50 foreign firms). ${ }^{6}$ The different sample sizes are also shown in Table 1 . We define foreign firms according to firms' survey responses to the question on the "nationality of ownership", i.e., any firm indicating a nationality different from "British" is treated as foreign.

Table 1 shows the composition of firm-ownership in the UK retail sector both for our sample and the population as indicated by FAME. The sample of firms used for the spillover analysis contains a total of 50 foreign-owned firms, amounting to 6.2 percent of all firms in the sample. The smaller sample used for the productivity spillover regressions contains a higher share of firms, with 11.4 percent of foreign-owned firms. This is, in general, similar to the proportion of foreign firms in the population of retail firms as reported in FAME. According to FAME, 12.1 percent of firms active by May 2008 and with more than

\footnotetext{
4 The SIC codes corresponding to these six retail subsectors are 521, 522, 523, 524, 525, and 526.

5 Details on the matching procedure can be obtained from the authors upon request.

${ }^{6}$ The number of foreign firms remains constant because these firms are only used to construct the spillover variables, i.e., foreign firms may report less data than domestic firms.
} 
10 employees in the retail sector are foreign owned. The largest foreign investors in the UK retail market come from the Republic of Ireland and the US, followed by Germany and France. The distribution of home countries of the foreign-owned firms used in the productivity analysis is consistent with the pattern of the population data in FAME. A comparison of the industry distribution between the final sample and the population also suggests that there is no significant selection bias in the final sample for our productivity analysis although the firm size in the small sample is slightly larger than that of the population.

[INSERT TABLE 1 HERE]

Table 2 contains summary statistics for some of the firm characteristics used in the regression analysis in Section V. The median number of employees is only 20, which corresponds to the small firm category. This shows that most of the firms in the sample are of small and medium size, while some firms are of significantly larger size. The age distribution of firms in the sample reveals that most firms are already in the market for a considerable length of time. Only about 12 percent of firms are aged 10 years or younger. As can be expected given the nature of the services provided in the retail market, the share of employees with university degrees in the sampled firms is very low. Nearly half of the firms report not to employ any university graduates. Regarding the ownership structure of UK retail firms, Table 2 shows that almost three quarter of the firms in the sample are family-owned, while 20 percent belong to a holding company. Finally, about 30 percent of firms sell also over the internet. ${ }^{7}$ A comparison of averages of these firm characteristics between the foreign and local firms are represented in Figure 1.

[INSERT TABLE 2 HERE]

\section{Methodology}

\section{Measurement of management capabilities}

The objective of our analysis is twofold. In the first place, we are interested in whether the presence of foreign-owned companies in the UK retail sector has had any effect on domestic firms' management capabilities. Secondly, we also investigate whether management capabilities possessed by foreign firms in the retail sector have had any effect on domestic firms' overall performance, measured as firm-level productivity. This allows us to test Hypotheses 1 to 3 outlined above.

\footnotetext{
${ }^{7}$ Out of the 1,004 firms covered in the survey, 304 firms report that they sell over the internet. We also have information on the share of internet sales in total sales. On average, internet sales are only a small part of total sales - the mean is $8.6 \%$. There are four firms that indicate a share of internet sales of 75 percent or above. All four firms are domestic companies; dropping these from the analysis does not affect our results.
} 
The empirical analysis requires two preliminary steps. The first step is to measure firms' management capabilities. There is little prior work on the quantitative measurement of management capabilities (CEML, 2002). Thompson and Heron (2005) produce a general management capabilities index by counting a number of variables which capture different dimensions of management capability including barriers to change, training philosophy, importance of management development, and indicators of internal labor markets for managers. In the literature on multinational enterprises, management skills are often proxied by the ratio of managerial workers to total workers (Caves 1974; Dunning, 1980; Saunders, 1982). Our questionnaire contains a firm's responses to 34 separate aspects of its management capabilities in form of a discrete rating. A large-scale study has demonstrated the validity of such subjective measures of company performance across multiple samples (Wall et al., 2004). The information contained in these questions can be compressed to reflect specific overarching areas of management expertise. The compressed information lends itself more easily to an intuitive interpretation and quantitative analysis. The second preliminary step is to compute firm-level productivity.

The first objective is achieved through exploratory factor analysis. Exploratory rather than confirmatory factor analysis appears to be the appropriate model given that our objective is to compress the information contained in a large number of variables into a drastically reduced number of variables representing broader areas of management capabilities. In order to remove firm-specific effects, we compute the average score of all responses within every management category for each firm and use this average to demean each single response within the corresponding management category. Details of the standard factor model are given in Appendix 2.

The data points towards four management capabilities, including 1) Skills and human resource management; 2) Operational management; 3) Incentive management; and 4) Marketing management. In addition, we also create an overall management capability variable comprising categories 1 ) to 4). Table 3 provides more detailed information on the management capability subcategories that compose the categories listed above. Given the estimated factor models for each management capability, we predict the corresponding factor scores as the conditional means of the latent variables given the observed variables. The factor scores, shown in Table 4, are then used in the spillover analysis. Whilst we postpone a more detailed discussion of Table 4 to Section $\mathrm{V}$, we note here that factor scores shown in Table 4 differ substantially between foreign and domestic firms.

[INSERT TABLEs 3 \& 4 HERE]

\section{Measurement of productive efficiency}


In order to obtain firm-level measures of productivity, instead of estimating a standard log-linear CobbDouglas production function, we opt for Data Envelopment Analysis (DEA) to compute firm efficiency. ${ }^{8}$ The centerpiece of DEA is the definition of a production possibility set within which all firms in the sample operate. This production possibility set contains all feasible combinations of input and output vectors given the sample. A single firm's efficiency is then defined by its relative location within the set and should thus be interpreted as the difference of a given firm with respect to the most productive firm in the sample. DEA, being a nonparametric approach, has an important advantage in that it does not require the specification of an explicit functional form of a firm's production function and as such does not assume the shape of the production function to be the same across firms. Because DEA is a deterministic, mathematical approach, the well-known problems associated with identification in the estimation of production functions (Ackerberg, et al, 2007; Bond and Söderbom, 2005) do not arise. This method also has a number of important drawbacks, most notably its sensitivity to outliers and measurement error of the variables used (van Biesebroeck, 2007). Considering the characteristics of our data, i.e., above all the fact that we only have a single cross-section of observations, DEA seems to be an appropriate approach and we have exerted great care to avoid our results being driven by outliers. Details on DEA are available in Appendix 3.

Measuring productivity in the service sector is a relatively more involved task than for manufacturing firms (for a review of the relevant literature see Añon-Higon et al., 2010). The most important distinction when measuring productivity of the retail sector is that the production function now should also include goods purchased for resale in addition to intermediate inputs (Manser, 2005). So a firm's turnover is the sum of value-added, intermediate inputs, as well as purchases of goods sold (Inklaar and Timmer, 2008). Hence, in order to compute TFP using a firm's sales as our output measure, we would need to take account of goods purchased for resale. ${ }^{9}$ Unfortunately, we only have data on a firm's primary inputs, capital and labor. We therefore note as a caveat that our efficiency scores may not accurately reflect true TFP. ${ }^{10}$ Another important issue arising in the estimation of productivity in the retail sector is service quality (Griffith and Harmgart, 2005). Since our questionnaire also contains information on firms' own perceptions of the quality of the services they provide, we used this information as an additional output as DEA allows us to relate any convex combination of outputs with inputs. However, the corresponding results are qualitatively very similar to the results obtained from the specification ignoring quality and are therefore not reported here.

\footnotetext{
${ }^{8}$ See also Keh and Chu (2003) for an application of DEA to computing retail productivity for US grocery stores.

${ }^{9}$ For their study of spillovers in the UK retail sector, Añon-Higon and Vasilakos (2008) estimate a log-linear production function having capital, labor and intermediate inputs as inputs in order to obtain TFP. It is, however, unclear whether these intermediate inputs contain goods purchased for resale, which would be required for correct specification of the retail production function.

${ }^{10}$ See Inklaar and Timmer (2008) for detailed discussion of the arising bias.
} 
For our measure of labor input, we use the number of employees indicated by firms in the questionnaire. We rely on self-reported employment by firms partly due to the lack of this information in FAME and ICC. Moreover, Añon-Higon et al. (2010) suggest that measuring labor input in the retail sector is particularly problematic due to the difficulty in tracing casual and part-time employment in officially reported data; hence, we believe that the measure reported by firms is more representative of the firms' actual labor input. Capital inputs are measured by tangible assets, which are taken from all three combined data sources, the survey, FAME, as well as ICC. Importantly, we use 2005 data to measure capital as data coverage in both FAME and ICC is extremely low for 2006 and 2007. We discuss possible identification issues due to this data selection in the next section.

\section{Estimation of FDI effects: competition and spillovers}

The predicted scores for the four management capabilities together with the overall measure of a firm's management capability are used in the spillover and productivity analysis. We use several specifications, each capturing different geographical, technological and competitive aspects of foreign managerial capabilities as discussed in Section II.

The first specification regresses a domestic firm j’s own factor score $M_{j i}^{D}$ of the specific management capability - where we have omitted superscripts $k$ for convenience - on the average score attained by foreign firms $\bar{M}_{i}^{F}$ in the same three digit SIC sector $i$ as the domestic firm.

Within Sector:

$$
M_{j i}^{D}=\beta_{j i}+\beta_{F i} \bar{M}_{i}^{F}+\beta_{X j} X_{j i}+\varepsilon_{j i}
$$

where $X_{j i}$ denotes a vector of firm-level covariates. Specification (1) is therefore attempting to reflect spillovers between technologically similar firms. ${ }^{11}$

To further refine the spillover measures, we used firms' postcodes to allocate firms by UK region. ${ }^{12}$ As a next step, we define the foreign spillover measure by region $r$ rather than by sector $i$ resulting in the slightly modified specification ${ }^{13}$. Specification (2) reflects geographically localized spillovers as follows.

\footnotetext{
11 Such a measure of technological proximity has been widely applied (Greenstone et al., 2007).

12 We have also matched firms to their county/unitary authority. However, our sample is distributed across 118 counties/unitary authorities, which leaves less than ten observations on average per county/unitary authority. We therefore limit ourselves to presenting the region-level results. Note that our approach of locating firms according to their postcodes may be problematic for multi-location firms, as the available postcode commonly only indicates the address of the headquarter or principal administrative site. Yet, since our sample consists mostly of small, familyowned, businesses (see Table 2), we are confident that our approach does well in identifying firms' locations.

${ }^{13}$ We have the following 13 regions: East Midlands, East of England, Highlands, London, North East, Northern Ireland, North West, Scotland, South East, South West, Yorkshire, West Midlands, and Wales.
} 
Within Region:

$$
M_{j r}^{D}=\beta_{j r}+\beta_{F r} \bar{M}_{r}^{F}+\beta_{X j r} X_{j r}+\varepsilon_{j r}
$$

In a third step, we combine the sector- and region-level information to regress a domestic firm's management score on the average foreign score within the same sector and region as follows.

Within Sector/Region: $\quad M_{j i r}^{D}=\beta_{j i r}+\beta_{\text {Fir }} \bar{M}_{i r}^{F}+\beta_{\text {Xjir }} X_{j i r}+\varepsilon_{j i r}$

Finally, we compute average foreign management capabilities for the same region but restrict the measure to all sectors different from the one the domestic company operates in.

$$
\text { Across Sector/Within Region: } \quad M_{j i r}^{D}=\beta_{j i r}+\beta_{F r} \sum_{i \neq l}^{L} \bar{M}_{l r}^{F}+\beta_{\text {Xjir }} X_{j i r}+\varepsilon_{j i r}
$$

Hence, this specification captures inter-industry competitive effects between domestic and foreign firms within a UK region. Specifications (3) and (4) combine the possibilities that spillovers arise both from competitive relationships as well as geographical distance or specific regional effects.

Equations (1) - (4) are estimated using OLS. ${ }^{14}$ As covariates, we use a range of continuous and binary variables. As such, we use the log of a firm's number of employees and the number of a firm's selling branches in the UK as a measure of overall firm size, ${ }^{15}$ the share of employees possessing a university degree, the log of a firm's age, and a measure for the perceived intensity of competition the firm is exposed to, which firms report in the questionnaire. ${ }^{16}$ The binary variables indicate whether a firm is family-owned, whether it is part of a group, and whether a firm also sells over the internet. Their summary statistics are shown in Table 2. Model specification tests suggest nonlinear relationships for the share of a firm's employees having a university degree and the number of a firm's branches. We therefore include for both variables also squared terms in (1) - (4).

We then proceed with regressing a domestic firm's productivity obtained from DEA on its own management capabilities and the foreign capability term as follows,

$$
E_{j i r}=\beta_{j i r}+\beta_{D j i r} M_{j i r}^{D}+\beta_{F i r} \bar{M}_{i r}^{F}+\beta_{X j i r} Z_{j i r}+\varepsilon_{j i r}
$$

14 Instead of relying on asymptotics, standard errors are obtained through bootstrapping since we are using predicted variables among the explanatory variables in the regressions. We use 399 bootstrap replications.

${ }^{15}$ For retail firms, the number of branches is an important characteristic due to the so-called chain effect, i.e., a retailer's ability to benefit from having more than a single store by, for example, spreading costs associated with advertizing or employee training across stores (Jia, 2008).

${ }^{16}$ The share of employees with a university can be regarded as a proxy for unobserved employee quality. Ideally, we would like to include the wage paid to employees in the conditioning set to account for differences between domestic and foreign firms, but the data is unavailable. 
Where $E_{j i r}$ denotes the efficiency measure for firm $j$ in sector $i$ in region $r . \bar{M}_{i r}^{F}$ is managerial capability spillovers measured by industrial and regional spillovers alternatively. $Z_{j i r}$ is a vector of control variables of retail efficiency. Coefficients $\beta_{D}$ capture the impact of a firm's own management capabilities on its efficiency and $\beta_{F}$ 's are the coefficients of various spillovers variables. In other words, $\beta_{F}$ reflects in how far variation in our spillover measures is correlated with variation in efficiency scores of domestic firms conditional on a firm's own management capabilities and a range of control variables.

Considering our data constraints, one important concern when assessing the importance of management spillovers on productivity is that firms may have responded to productivity realizations based on inputs in 2005 with adjustment in their levels of management capability in 2007. This issue could arise given that we only have a measure for capital for 2005. In this case, the spillover coefficients would not be identified. From a management theoretical perspective it is unlikely that firms are able to adjust their management capacities so quickly. This is due to the fact that unlike labor and intermediate inputs, management skills are a dynamic input and accumulate over time. Especially, as discussed in Section II, the acquisition of new management capabilities not only requires learning of new skills but also the replacement of existing skills which may not be complementary. This may be particularly challenging when management capabilities are embedded in organizational structures and management systems of companies. One way of verifying whether this is a valid concern for our data, is to use the answers to questions on each management capacity on the duration of a firm having capacity in the specific management capability. The questionnaire specifically asks firms to indicate the number of years "with at least a great deal of capability" in the respective management skill. This information can be exploited to check how sensitive changes of management capacity are over time to changes in productivity. This information allows us to analyze whether there exists any correlation between the number of years reported by a firm and its productivity. If a firm responded to its productivity realizations through changes in its management capacity, we would find a systematic correlation between firms reporting to have capabilities only for a short number of years and their respective productivity levels. To do this, apart from graphical tests, we grouped firms into deciles according to the distribution of the durations reported for each management capability and then regressed management skills by these deciles on productivity. If firms responded to productivity by adjustments in the management capabilities in recent years, we would observe some systematic correlation across deciles defined for short durations and productivity. The results show that there is no such systematic statistically significant correlation between a firm's reported management capability by duration deciles and productivity, i.e., firms do not seem to have responded to recent productivity realizations with adjustment in their management capacities. ${ }^{17}$

\footnotetext{
17 Detailed results are available from the authors upon request.
} 
Equation (5) is estimated using OLS and Tobit. Previous work using DEA efficiency scores applied Tobit instead of OLS in order to correct for clustering of efficiency scores at the boundary values which are by construction equal to zero and one (e.g., Kirjavainen and Loikkanen, 1998). Yet, in our data, there is little evidence for such clustering of the efficiency scores; only 3.7 percent of firms attain a score of one and less than 5 percent of firms obtain a score of less than 0.05 . We nevertheless report Tobit estimates as a robustness check. ${ }^{18}$

\section{Results}

Table 4 showed summary statistics for the management capability scores predicted using factor analysis both for domestic and foreign firms. Means are centered around zero for the entire distribution, so means for foreign firms can roughly be interpreted as deviations from the mean of domestic firms, because domestic firms represent 94 percent of the sample used to construct the statistics shown in Table 4 . Hence, we see that foreign firms have on average higher management capabilities for the overall factor score and the subcategories HRM, Operations and Marketing. On the other hand, scores achieved by foreign firms for the subcategory Incentives are lower than those attained by domestic firms. Minimum and maximum scores reveal that less foreign firms achieve very low scores but also less foreign firms achieve very high scores in comparison to domestic firms. Comparison of individual scores of management capabilities reveals consistent picture of stronger capabilities in foreign than local firms. This finding is consistent for firms in different size groups (small: $<50$, medium: 50-250 and large: $>250$ ). ${ }^{19}$

Tables 5 and 6 show the results for the spillover regressions specified in Equations (1)-(4). Most of the estimated coefficients of the various capability spillover variables are not statistically significant. This is not surprising given the tacit, context-dependent and imperfectly imitable nature of capabilities as suggested by Teece and Pisano (1994). Moreover, the estimated coefficients of the overall management capacity score for specifications (2) and (4) are negative and statistically significant at the 10 and 5 percent significance level, respectively. This result suggests that foreign management capabilities have exerted a marginally significant negative competition effect on domestic firms in the same region. The result using specification (4) suggests that the intra-region competition effect comes from inter-industry competition. However, human resource management related capabilities, i.e. skills and human resource management and incentive management capabilities, have exerted some positive horizontal spillovers on domestic firms in the same SIC 3-digit industry. This is likely due to the more codified knowledge and practices in human resource management which spills over more easily through demonstration effects, labor movement between foreign and local firms, and informal word-of-mouth spread among employees from different firms. The low $\mathrm{R}^{2}$ obtained for all the regressions suggests that the model fits the data poorly.

18 As for the spillover regressions, instead of relying on asymptotic standard errors, we obtain bootstrap standard errors where we use again 399 bootstrap replications.

${ }^{19}$ Results are not included in the paper due to space limitation. They are available subject to request. 
Due to the tacit, intangible and comprehensive nature of capabilities, this is understandable. It also points to the direction of future research to better assess and model capabilities, which is crucial to a firm's competitive advantage. These findings lend support to half of our Hypotheses 1 and 2, i.e. (a) and (c) for H1 and (b) and (d) for H2 (as shown in Table 8).

\section{[INSERT TABLES 5 \& 6 HERE]}

Regarding productivity, Figure 2 provides evidence on differences in the efficiency distributions across domestic and foreign firms. The density distributions show that foreign firms achieve relatively higher efficiency scores than domestic firms at higher percentiles of the efficiency distribution. On average, the productive efficiency score of foreign firms is 27 percent higher than that of local firms. Their difference is small at the lower end, for example, the gap in efficiency score between foreign and local firms is only $3 \%$ at the 25 percentile. However, this gap becomes substantial and significant at the higher end of the efficiency distribution. At the 75 percentile, the efficiency gap between foreign and local firms is as high as $38 \%$. These findings are in-line with the literature on foreign investment and firm performance for the UK (Criscuolo and Martin, 2005; Griffith et al., 2004; Añon-Higon and Vasilakos, 2008; Fu, 2009).

Table 7 reports the OLS and Tobit results for spillover effects on the efficiency of domestic UK retailers which were defined in equation (5). ${ }^{20}$ We limit the presentation in Table 7 to the overall management capability score as using the other management capabilities provides overall qualitatively identical results. Using the efficiency score obtained from employing sales as a single output and capital and labor as inputs, we find a statistically significant association of a firm's own management capability and its efficiency score for the overall management capability score for all four spillover specifications. However, foreign management capabilities do not appear to have a significant effect on productive efficiency of local retailers, substantiating our Hypothesis 3. This is likely due to two reasons. First, the insignificant effect may be a result of the combination of the two faces of foreign management capabilities, competitive pressure on one hand and knowledge spillovers on the other. Second, it takes time for local firms to (a) identify and imitate useful foreign management capabilities, (b) built them into the firms' existing capability portfolio and (c) translate these new capabilities into higher efficiency. In terms of other control variables, we find a consistent negative and significant coefficient on the number of employees but positive and significant coefficients on the share of employees with university degrees and the number of branch stores.

\footnotetext{
20 To check the robustness of our results, we use a parametric stochastic frontier approach (SFA) to estimate firmlevel efficiency since the stochastic approach is less sensitive to outliers than DEA. However, the results obtained from using DEA efficiency scores are qualitatively very similar to those obtained from employing SFA efficiency measures. We also examined spillover effects of management capabilities on the efficiency of firms for small and medium sized firms. The results are broadly similar to the full sample results. For brevity, these results are not reported here but are available from the authors.
} 
[INSERT TABLE 7 HERE]

[INSERT TABLE 8 HERE]

\section{Conclusions}

Using survey data for the UK retail sector, this paper examines whether there exist capability spillovers from foreign to domestic firms and whether these spillovers have any effect on domestic firm management capabilities and performance measured as firm-level efficiency. On average, foreign-owned retail firms appear to be more productive than domestic firms and enjoy higher scores for our management capability measures. Using several measures to capture horizontal, vertical and regional spillovers, we find limited evidence for the existence of statistically significant capability spillovers originating from foreign to domestic firms confirming the tacit, context-dependent and imperfectly imitable nature of capabilities.

Our results suggest two faces of foreign management capabilities. On one hand, capabilities that are more likely to be codified, i.e., human resource management capabilities, generate some spillovers on the relevant management capabilities of local firms. On the other hand, those foreign management capabilities which are more tacit and firm-specific have exerted a statistically significant negative competition effect on domestic firms that are located within the same UK regions as the foreign-owned companies. There appears to be no robust link between foreign management capabilities and domestic firm performance measured as firm efficiency. However, firms' own overall management capacity is positively associated with their productive efficiency. Considering the limitations of our analysis imposed by the availability of longitudinal data, conclusions need to be drawn with caution and causal statements are not warranted.

There are some policy implications that arise with regard to the use of FDI in the retail sector for countries in both the developed and developing countries. First, internationalization of retailing has been a major trend in the past two decades. Retail transnational corporations have expanded not only to the developed economies in the West, but also the emerging markets which have grown rapidly. Opening up the retail market to the MNEs is expected to provide better services to the consumers and also enhance the capabilities of local retailers through knowledge transfer. Our results show that in the retail sector, which is capital-intensive and which is increasingly using sophisticated management practices and strategies at the management-level in various management areas, MNEs appear to represent more a source of competitive pressure than of knowledge spillovers. The competition to the small and medium retailers could be substantial. Policy makers need to be informed about the two-sides of the impact on local firms of opening up such service sectors to foreign investment, especially the asymmetric strength of competition and spillovers effects on small retailers. Appropriate policies, such as training of managers as 
well as employees and improvement of IT infrastructure as well as policies ensuring fair competition are needed for local firms to build up their own capabilities in the face of direct foreign competition. Such policies are important not only in the UK where the current study is based; they will be of greater importance in emerging and developing countries where management capabilities of local firms are much weaker than that of local firms in developed countries. Second, our empirical results support the notion that managerial capabilities are an important dimension of core competitiveness of firms. Building managerial capabilities should be a priority in firms' development and competition strategy. Some codifiable management practices and techniques can be imitated but their effectiveness is contextual. Therefore identifying the most suitable 'best practices' used by MNEs and adapting them within in a firmspecific context will create value to a local retail firm. At the same time, local managers should also realize that many tacit capabilities are difficult to imitate and have to be built up through intensive learning and training. Therefore, a combination of internal capabilities building and transfer of suitable 'best practices' should be a strategic choice for local retail managers to confront the challenge of foreign competition. 


\section{Bibliography}

Ackerberg, D., L. Benkard, S. Berry, A. Pakes. 2007. Econometric tools for analyzing market outcomes, J. J. Heckman, E. E. Leamer, eds. Handbook of Econometrics. Vol. 6A. Elsevier, 4171-4276.

Aghion, P., N. Bloom, R. Blundell, R. Griffith, P. Howitt. 2005. Competition and innovation: An inverted U relationship. Quarterly Journal of Economics. 120(2) 701-728.

Aitken, B. J., A. Harrison. 1999. Do domestic firms benefit from direct foreign investment? Evidence from Venezuela. American Economic Review. 83(3) 605-618.

Alcácer, J., W. Chung. 2007. Location strategies and knowledge spillovers. Management Science. 53(5) 760776.

Añón-Higón, D., N. Vasilakos. 2008. Productivity, multinationals and knowledge spillovers: Evidence from the UK retail sector. Munich Personal RePEc Archive, available at http://mpra.ub.unimuenchen.de/7181/.

Añón-Higón, D., Bozkurt, Ö., Clegg, J., Grugulis, I., Salis, S., Vasilakos, N., and Williams, A.M., 2010, "The Determinants of Retail Productivity: A Critical Review of the Evidence", International Journal of Management Review. 12 (2) 201-227

Arellano, M., S. Bond. 1991. Some tests of specification for panel data: Monte Carlo evidence and an application to employment equations. Review of Economic Studies. 58(2) 277-297.

Audretsch, D., M. Feldman. 1996. R\&D spillovers and the geography of innovation and production. American Economics Review. 86(3) 630-640.

Banker, R. D., A. Charnes, W. W. Cooper. 1984. Some models for estimating technical and scale inefficiencies in data envelopment analysis. Management Science. 37(6) 733-738.

Blomstrom, M., A. Kokko. 1998. Multinational corporations and spillovers. Journal of Economic Surveys. $12(2) 1-31$.

Bloom, N., J. Van Reenen. 2007. Measuring and Explaining Management Practices across Firms and Countries. Quarterly Journal of Economics. 122(4) 1351-1408.

Bloom, N., J. Van Reenen. 2010. Why Do Management Practices Differ across Firms and Countries? Journal of Economic Perspectives. 24(1) 203-224.

Blundell, R., S. Bond. 2000. GMM estimation with persistent panel data: An application to production functions. Econometric Reviews. 19(3) 321-340.

Bond, S., M. Söderbom. 2005. Adjustment costs and the identification of Cobb Douglas production functions. IFS WP05/04.

Breschi, S., F. Lissoni. 2001. Knowledge spillovers and local innovation systems: A critical survey. Industrial and Corporate Change. 10(4) 975-1004.

Buckley, P., Clegg, J. \& Wang, C. 2002. The impact of inward FDI on the performance of Chinese manufacturing firms. Journal of International Business Studies. 33(4) 637-655. 
Buckley, P., Clegg, J. \& Wang, C., 2007a. Is the relationship between inward FDI and spillover effects linear? An empirical examination of the case of China. Journal of International Business Studies. 38(3) 447-459.

Buckley, P., Wang, C., and Clegg, J. 2007b. The impact of foreign ownership, local ownership and industry characteristics on spillover benefits from foreign direct investment in China. International Business Review.16(2) 142-158.

Cantwell, J. 1991. A survey of theories of international production. in Roger Sugden and Christos N Pitelis (eds.), The Nature of the Transnational Firm, Routledge, London, UK.

Carlsson , B., G. Eliasson. 1994. The nature and importance of economic competence. Industrial and Corporate Chanege. 3(3) 687-711.

Caves, R. E. 1974. Multinational firms, competition and productivity in host-country markets. Economica, 41(162) 176-193.

Celia, H., Iona, A., Petrescu, A., Clegg, C., Battisti, G. and Fu, X., 2008. Understanding Retail Capabilities, survey report to the EPSRC.

CEML (2002) Managers and Leaders: Raising our Game, Council for Excellence in Management and Leadership. DTI, London, UK.

Cohen, W., D. Levinthal. 1989. Innovation and learning: Two faces of R\&D. Economic Journal. 99(397) 569-596.

Criscuolo C., R. Martin. 2005. Multinationals and US productivity leadership: Evidence from Great Britain. CEP Discussion Paper No. 672.

Dunning, J. H. 1958. American Investment in British Manufacturing Industry. Allen and Unwin, London, UK.

Dunning, J. H. 1980. Toward an eclectic theory of international production: some empirical tests. Journal of International business Studies. 11 (1) 9-31.

Dunning, J. H. 1988. The eclectic paradigm of international production: A restatement and some possible extension. Journal of International Business Studies. 19(1) 1-31.

Farrell, M. J. 1957. The measurement of productive efficiency. Journal of Royal Statistical Society, Series A, (General) 120(3) 253-281.

Fortanier, F. and van Wijk, J. 2010. Sustainable tourism industry development in sub-Saharan Africa: Consequences of foreign hotels for local employment. International Business Review. 19(2) 191-205.

$\mathrm{Fu}, \mathrm{X}$. 2004. Limited linkages from growth engines and regional disparities in China. Journal of Comparative Economics. 32(1) 148-164.

Fu, X. 2009. Managerial knowledge spillovers from FDI: Evidences from British establishments. University of Oxford, SLPTMD Working Paper No. 035.

Görg, H., E. Strobl. 2001. Multinational companies and productivity spillovers: A meta-analysis. Economic Journal. 111(475) F723-F739. 
Greenstone, M., R. Hornbeck, E. Moretti. 2007. Identifying agglomeration spillovers: Evidence from million dollar plants. MIT Department of Economics Working Paper No. 07-31.

Griffith, R., H. Harmgart. 2005. Retail productivity. The International Review of Retail, Distribution and Consumer Research. 15(3) 281-290

Griffith, R., S. Redding, H. Simpson. 2004. Foreign ownership and productivity: New evidence from the service sector and the R\&D lab. CEP Discussion Paper No 649.

Hambrick, D. C., P. A. Mason. 1984. Upper echelons: The organization as a relection of its top managers. Academy of Management Review. 9(2) 193-206.

Hamida, L.B. and Gugler, P. 2009. Are there demonstration-related spillovers from FDI? Evidence from Switzerland. International Business Review. 18(5), 494-508.

Inklaar, R., M. Timmer. 2008. Accounting for growth in retail trade: An international productivity comparison. Journal of Productivity Analysis. 29(1) 23-31.

Jia, P. 2008. What Happens When Wal-Mart Comes to Town: An Empirical Analysis of the Discount Industry. Econometrica. 76(6), 1263-1316.

Keh, H. T., S. Chu. 2003. Retail productivity and scale economies at the firm level: A DEA approach. Omega. 31(2) 75-82.

Kirjavainen, T., H. Loikkanen. 1998. Efficiency differences of Finnish senior secondary schools: An application of DEA and Tobit analysis. Economics of Education Review. 17(4) 377-394.

Knott, A. M., H. Posen, B. Wu. 2008. Spillover asymmetry and why it matters. Management Science, 1-16..

Lado, A., M. Wilson. 1994. Human resource system and sustained competitive advantage: Competencybased perspective. Academy of Management Review. 19(4) 699-727.

Levinsohn, J., A. Petrin. 2003. Estimating production functions using inputs to control for unobservables. Review of Economic Studies. 70(2) 317-341.

Manser, M. 2005. Productivity measures for retail trade: data and issues. Monthly Labor Review. 30-38.

Miozzo, M. and Grimshaw, D. 2008. Service multinationals and forward linkages with client firms: The case of IT outsourcing in Argentina and Brazil. International Business Review. 17 (1) 8-27.

Molina, M. A., I. B. del Pino, A. C. Rodriguez. 2004. Industry, management capabilities and firms' competitiveness: An empirical contribution. Managerial and Decision Economics. 25(5) 265-281.

Nelson, R., S. Winter. 1982. An Evolutionary Theory of Economic Change. Harvard University Press, Cambridge, MA.

Saunders, R. S. 1982. The determinants of interindustry variation of foreign ownership in Canadian manufacturing. Canadian Journal of Economics. 15(1) 77-84.

Teece, D., G. Pisano. 1994. The dynamic capabilities of firms: an introduction. Industrial and Corporate Change. 3(3) 537-556.

Teece, D. J. 1976. The Multinational Corporation and the Resource Cost of International Technology Transfer. Ballinger, Cambridge, MA. 
Thompson, M., P. Heron. 2005. Management capability and high performance work organisation. International Journal of Human Resource Management. 16(6) 2019-2048.

Tushman, M. L., E. Romanelli. 1985. Organisational evolution: A metamorphosis model of convergence and reorientation. L. L. Cummings, B. M. Staw, eds. Research in Organizational Behavior, Vol. 7. JAI Press Greenwich, CT, 171-222.

UNCTAD. 2005. Globalisation of R\&D and developing countries: Proceedings of an expert meeting. United Nations, New York and Geneva.

van Biesebroeck, J. 2007. Robustness of productivity estimates. Journal of Industrial Economics. 55(3) 529569.

Wall, T. D., J. Michie, M. Patterson, S. J. Wood, M. Sheehan, C.W. Clegg, M. A. West. 2004. On the validity of subjective measures of company financial performance. Personnel Psychology. 57(1) 95-118.

Wesley, F., H. Mintzberg. 1989. Visionary leadership and strategic management. Strategic Management Journal. 10(1) 17-32.

Wrigley, N. (2000), “The Globalization of Retail Capital: Themes for Economic Geography”, in Clark, G.L., Feldman, P. and Gertler, M.S. (eds), The Oxford Handbook of Economic Geography. Oxford: Oxford University Press, pp.292-313.

Wölfl, A. 2005. The service economy in OECD countries. STI Working Paper 2005/03, OCED. 
Figure 1: Comparison of averages of firm characteristics of foreign and local retailers

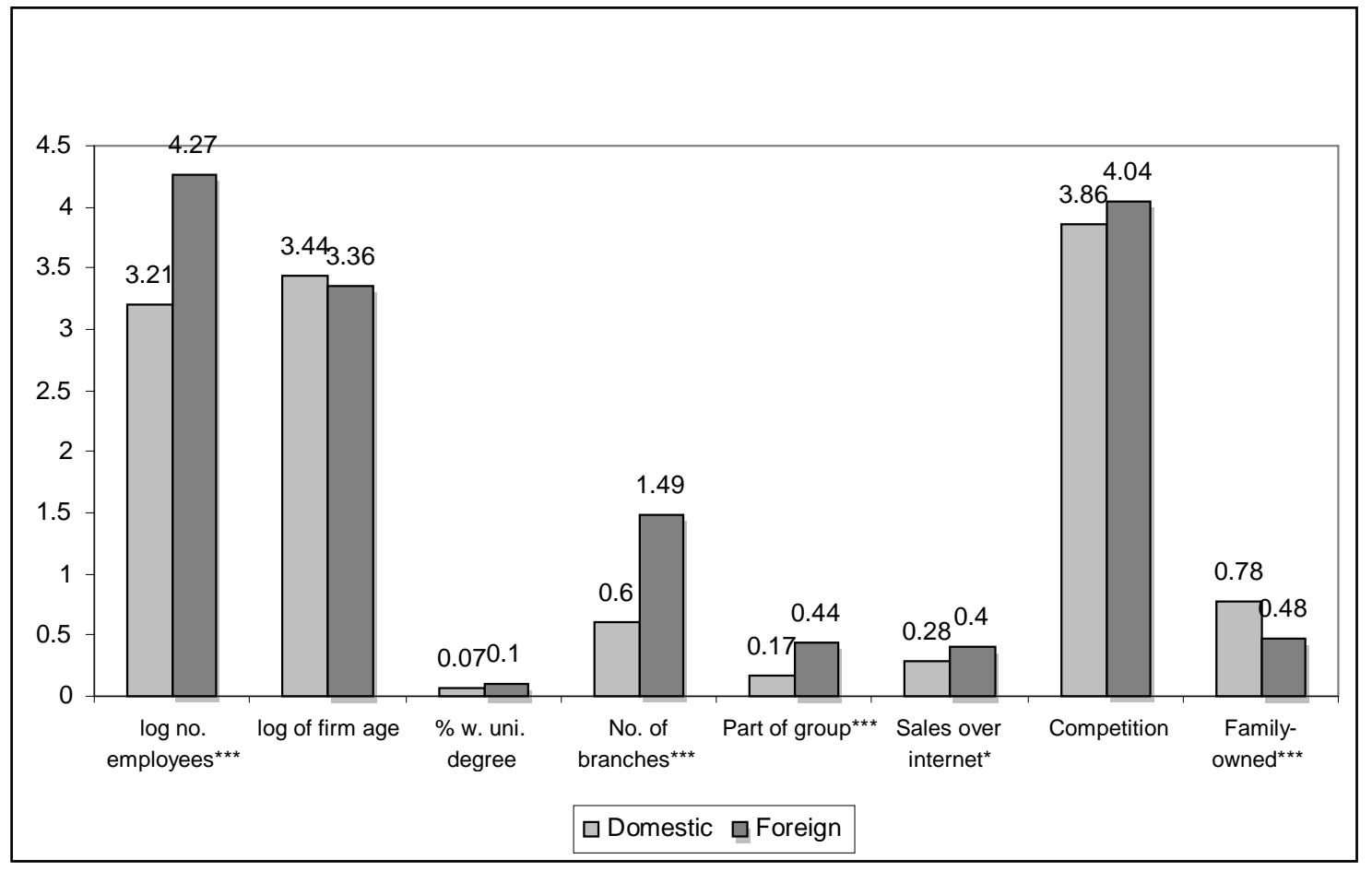

Notes: ${ }^{* *}$ Significant at $1 \%$ level; $* *$ Significant at $5 \%$ level and $*$ Significant at $10 \%$ level. 
Figure 2: Distribution of efficiency of foreign and local retail firms

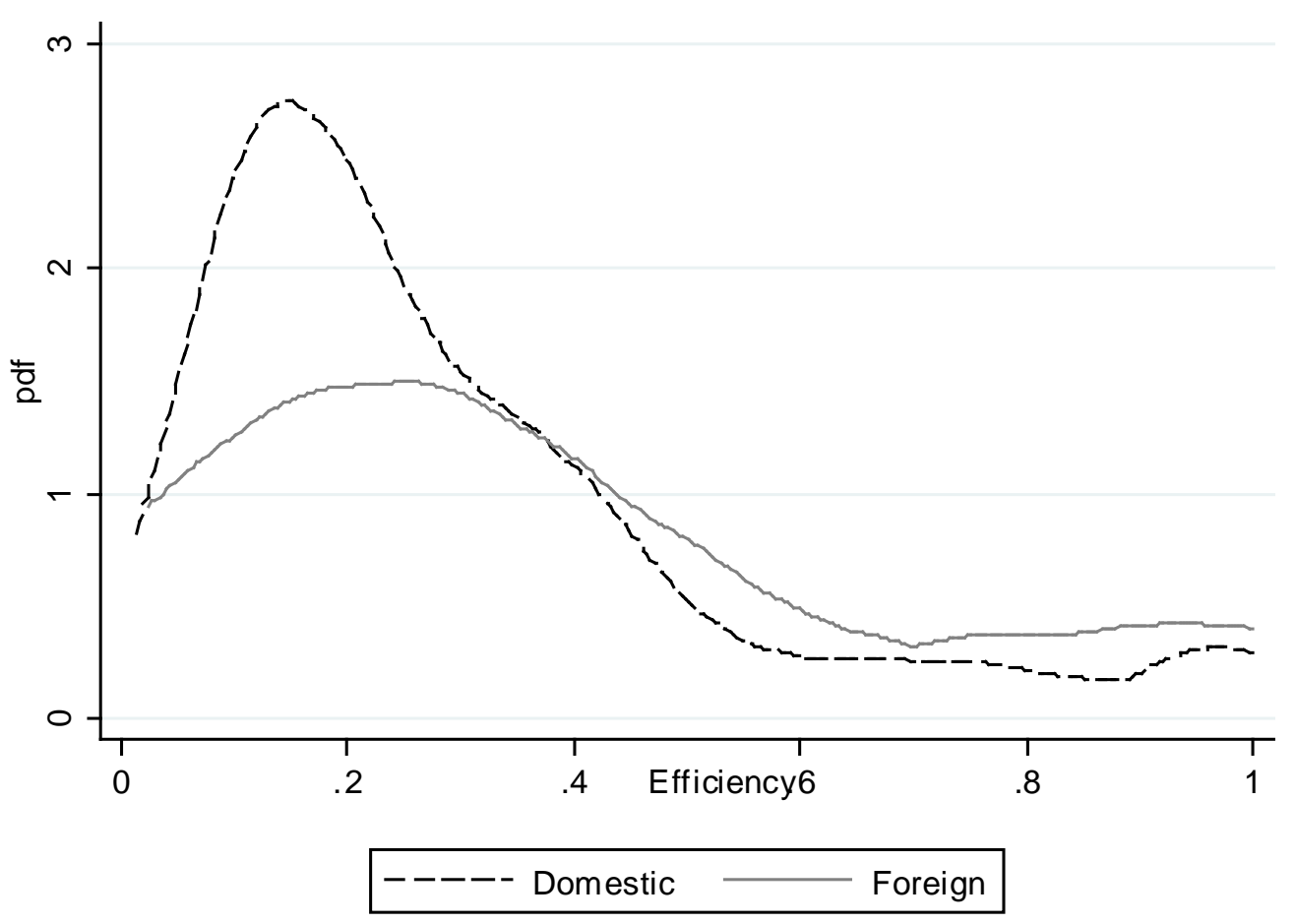


Table 1: Comparison foreign ownership sample / population

\begin{tabular}{|c|c|c|c|c|c|c|c|c|}
\hline & \multicolumn{4}{|c|}{ Sample } & \multicolumn{4}{|c|}{ Population (FAME) } \\
\hline & \multicolumn{2}{|c|}{ Spillover } & \multicolumn{2}{|c|}{ Productivity } & \multicolumn{2}{|c|}{ Active } & \multicolumn{2}{|c|}{$\begin{array}{l}\text { Active \& No. of } \\
\text { employees }>=10\end{array}$} \\
\hline & No. & $\%$ & No. & $\%$ & No. & $\%$ & No. & $\%$ \\
\hline Domestic & 757 & 93.8 & 389 & 88.6 & 91,318 & 98.5 & 1,622 & 87.9 \\
\hline Foreign & 50 & 6.2 & 50 & 11.4 & 1,352 & 1.5 & 223 & 12.1 \\
\hline
\end{tabular}

Notes: 1) For our sample, 'foreign' is defined by firms' response to a question on the nationality of ownership (see Appendix 1). Any firm not reporting British as nationality is regarded as foreign. Of the foreign firms, $16 \%$ are MNEs from the US, 14\% from Germany, 14\% from France, 12\% from Ireland, 6\% are Chinese MNEs and 38\% are MNEs retailers from other foreign countries.

2) For FAME, 'foreign' is defined by the nationality of a firm's ultimate holding company. Any firm belonging to an ultimate holding that is not British is regarded as foreign.

Table 2: Summary statistics: Firm characteristics

\begin{tabular}{lcccccc}
\hline Variable & Obs. & Mean & S.D. & Min & Median & Max \\
\hline Domestic Firms & & & & & & \\
\hline No. Employee & 757 & 58.73 & 328.29 & 10 & 20 & 6,300 \\
Age & 757 & 42.34 & 38.10 & 3 & 30 & 258 \\
\% of employees with & 757 & $7.49 \%$ & $13.17 \%$ & 0 & $1.67 \%$ & 1 \\
university degree & 757 & 4.24 & 24.05 & 1 & 1 & 493 \\
No. of branches & 757 & 0.17 & 0.37 & 0 & 0 & 1 \\
Part of Holding & 757 & 0.78 & 0.41 & 0 & 1 & 1 \\
Family-owned & 757 & 0.28 & 0.45 & 0 & 0 & 1 \\
Internet sales $\$$ & "In & &
\end{tabular}

Note: "Internet sales" is a binary variable indicating whether the firms sell over the internet. 
Table 3: Management Capability Categories

\begin{tabular}{ll}
\hline \multicolumn{1}{c}{ Management capability } & \multicolumn{1}{c}{ Subcategories } \\
\hline Skills and human resource management & (a) Attracting, selecting, and retaining high quality staff \\
\hline & (b) Staff training, auditing, and guidance \\
Operational management & (c) Staff work organisation \\
& (d) Management of inventories \\
\hline Incentive management & (e) Organisation of work on shop floor \\
& (f) Staff employer relationship \\
Marketing management & (g) Provision of incentives to staff \\
\hline
\end{tabular}

Table 4: Management Capability Scores

\begin{tabular}{llcccccc}
\hline \hline \multirow{2}{*}{ Overall } & & Obs. & Mean & S.D. & Min & Median & Max \\
& Local & 757 & -0.021 & 0.969 & -3.554 & -0.054 & 2.529 \\
\multirow{3}{*}{ HRM } & Loreign & 50 & 0.094 & 0.963 & -1.801 & -0.031 & 2.205 \\
& Foral & 757 & -0.039 & 0.923 & -2.663 & -0.082 & 2.689 \\
\multirow{3}{*}{ Operation } & 50 & 0.049 & 0.935 & -1.670 & -0.143 & 1.929 \\
& Local & 757 & 0.007 & 0.919 & -3.290 & 0.015 & 2.932 \\
& Foreign & 50 & 0.076 & 0.930 & -1.894 & -0.020 & 1.906 \\
& Local & 757 & -0.025 & 0.918 & -2.430 & -0.122 & 2.873 \\
\multirow{3}{*}{ Marketing } & Local & 757 & -0.021 & 0.926 & -3.079 & -0.025 & 2.743 \\
& Foreign & 50 & 0.137 & 0.957 & -1.573 & 0.035 & 2.384 \\
\hline \hline
\end{tabular}


Table 5: Spillover Regression for Equations (1) and (2)

\begin{tabular}{|c|c|c|c|c|c|c|c|c|c|c|}
\hline \multirow{3}{*}{ Dependent variable } & \multicolumn{5}{|c|}{ Within Sector } & \multicolumn{5}{|c|}{ Within Region } \\
\hline & Overall & HRM & Operation & Incentive & Marketing & Overall & HRM & Operation & Incentive & Marketing \\
\hline & $5-1$ & $5-2$ & $5-3$ & $5-4$ & $5-5$ & $5-6$ & $5-7$ & $5-8$ & $5-9$ & $5-10$ \\
\hline \multirow[t]{2}{*}{ Foreign MC } & -0.047 & $0.993 *$ & 0.374 & 0.240 & -0.143 & $-0.120^{*}$ & 0.051 & -0.039 & 0.116 & -0.017 \\
\hline & $(0.364)$ & $(0.593)$ & $(0.458)$ & $(0.537)$ & $(0.287)$ & $(0.071)$ & $(0.065)$ & $(0.104)$ & $(0.115)$ & $(0.097)$ \\
\hline \multirow[t]{2}{*}{ log no. employees } & $0.108^{*}$ & -0.020 & 0.041 & -0.066 & 0.015 & $0.109 * *$ & -0.020 & 0.042 & -0.070 & 0.017 \\
\hline & $(0.045)$ & $(0.035)$ & $(0.050)$ & $(0.042)$ & $(0.044)$ & $(0.049)$ & $(0.035)$ & $(0.046)$ & $(0.042)$ & $(0.047)$ \\
\hline \multirow[t]{2}{*}{ log of firm age } & 0.022 & 0.024 & -0.047 & -0.023 & -0.036 & 0.019 & 0.020 & -0.052 & -0.027 & -0.039 \\
\hline & $(0.036)$ & $(0.030)$ & $(0.032)$ & $(0.034)$ & $(0.037)$ & $(0.036)$ & $(0.032)$ & $(0.035)$ & $(0.032)$ & $(0.034)$ \\
\hline \multirow[t]{2}{*}{$\% \mathrm{w}$. uni. degree } & 0.375 & $-0.984^{* *}$ & 0.839 & 0.341 & 0.693 & 0.302 & $-1.015^{* *}$ & 0.843 & 0.357 & 0.693 \\
\hline & $(0.516)$ & $(0.461)$ & $(0.538)$ & $(0.426)$ & $(0.575)$ & $(0.551)$ & $(0.480)$ & $(0.506)$ & $(0.465)$ & $(0.584)$ \\
\hline \multirow{2}{*}{$\%$ w. uni. degree sq. } & -0.351 & $1.580^{* *}$ & -1.224 & -0.857 & $-1.824 * *$ & -0.220 & $1.608^{* *}$ & -1.215 & -0.876 & $-1.823^{* *}$ \\
\hline & $(0.710)$ & $(0.694)$ & $(0.811)$ & $(0.659)$ & $(0.749)$ & $(0.774)$ & $(0.716)$ & $(0.795)$ & $(0.708)$ & $(0.751)$ \\
\hline \multirow[t]{2}{*}{ No. of branches } & 0.088 & 0.079 & $0.116^{*}$ & 0.042 & -0.025 & $0.094 *$ & 0.077 & $0.116^{*}$ & 0.043 & -0.027 \\
\hline & $(0.078)$ & $(0.064)$ & $(0.075)$ & $(0.064)$ & $(0.074)$ & $(0.073)$ & $(0.069)$ & $(0.075)$ & $(0.066)$ & $(0.078)$ \\
\hline \multirow[t]{2}{*}{ No. of branches sq. } & $-0.062 * *$ & -0.014 & -0.028 & 0.008 & 0.011 & $-0.064 * *$ & -0.013 & -0.028 & 0.008 & 0.011 \\
\hline & $(0.024)$ & $(0.024)$ & $(0.026)$ & $(0.019)$ & $(0.024)$ & $(0.023)$ & $(0.027)$ & $(0.027)$ & $(0.019)$ & $(0.026)$ \\
\hline \multirow[t]{2}{*}{ Part of group } & -0.000 & -0.120 & $0.160^{*}$ & 0.085 & -0.047 & 0.000 & -0.110 & $0.168^{* *}$ & 0.090 & -0.041 \\
\hline & $(0.091)$ & $(0.067)$ & $(0.085)$ & $(0.098)$ & $(0.092)$ & $(0.096)$ & $(0.070)$ & $(0.084)$ & $(0.090)$ & $(0.091)$ \\
\hline \multirow[t]{2}{*}{ Sells over internet } & -0.090 & 0.069 & -0.092 & -0.073 & -0.019 & -0.090 & 0.069 & -0.095 & -0.069 & -0.019 \\
\hline & $(0.077)$ & $(0.062)$ & $(0.069)$ & $(0.071)$ & $(0.075)$ & $(0.073)$ & $(0.059)$ & $(0.070)$ & $(0.062)$ & $(0.075)$ \\
\hline \multirow[t]{2}{*}{ Competition measure } & -0.018 & -0.005 & -0.039 & -0.014 & -0.010 & -0.017 & -0.007 & -0.038 & -0.011 & -0.009 \\
\hline & $(0.034)$ & $(0.028)$ & $(0.032)$ & $(0.030)$ & $(0.032)$ & $(0.037)$ & $(0.027)$ & $(0.032)$ & $(0.030)$ & $(0.032)$ \\
\hline \multirow[t]{2}{*}{ Family-owned } & 0.092 & 0.025 & 0.060 & 0.058 & $0.188^{* *}$ & 0.091 & 0.024 & 0.061 & 0.062 & $0.187 * *$ \\
\hline & $(0.080)$ & $(0.065)$ & $(0.072)$ & $(0.073)$ & $(0.083)$ & $(0.077)$ & $(0.060)$ & $(0.067)$ & $(0.076)$ & $(0.081)$ \\
\hline \multirow[t]{2}{*}{ Constant } & -0.393 & -0.363 & 0.096 & 0.308 & -0.253 & -0.392 & -0.022 & 0.151 & 0.268 & -0.201 \\
\hline & $(0.262)$ & $(0.285)$ & $(0.234)$ & $(0.270)$ & $(0.297)$ & $(0.271)$ & $(0.206)$ & $(0.223)$ & $(0.212)$ & $(0.239)$ \\
\hline R-squared & 0.008 & 0.004 & 0.023 & 0.009 & 0.029 & 0.012 & 0.002 & 0.022 & 0.007 & 0.029 \\
\hline $\mathrm{N}$ & 757 & 757 & 757 & 757 & 757 & 757 & 757 & 757 & 757 & 757 \\
\hline
\end{tabular}

$* \mathrm{p}<0.10,{ }^{* *} \mathrm{p}<0.05, * * * \mathrm{p}<0.01$
All regressions include industry dummies

Bootstrap standard errors; Regressions only on sample of domestic firms 
Table 6: Spillover Regression for Equations (3) and (4)

\begin{tabular}{|c|c|c|c|c|c|c|c|c|c|c|}
\hline \multirow{3}{*}{ Dependent variable } & \multicolumn{5}{|c|}{ Within Sector/Region } & \multicolumn{5}{|c|}{ Across Sector/Within Region } \\
\hline & Overall & HRM & Operation & Incentive & Marketing & Overall & HRM & Operation & Incentive & Marketing \\
\hline & $6-1$ & $6-2$ & $6-3$ & $6-4$ & $6-5$ & $6-6$ & $6-7$ & $6-8$ & $6-9$ & $6-10$ \\
\hline \multirow[t]{2}{*}{ Foreign MC } & 0.017 & 0.042 & 0.025 & $0.081 *$ & -0.014 & $-0.151 * *$ & 0.026 & -0.027 & 0.024 & 0.014 \\
\hline & $(0.063)$ & $(0.098)$ & $(0.058)$ & $(0.046)$ & $(0.079)$ & $(0.063)$ & $(0.054)$ & $(0.055)$ & $(0.067)$ & $(0.092)$ \\
\hline \multirow[t]{2}{*}{ log no. employees } & $0.109^{*}$ & -0.020 & 0.043 & -0.068 & 0.017 & $0.112^{*}$ & -0.021 & 0.043 & -0.067 & 0.018 \\
\hline & $(0.044)$ & $(0.035)$ & $(0.050)$ & $(0.040)$ & $(0.043)$ & $(0.050)$ & $(0.036)$ & $(0.047)$ & $(0.043)$ & $(0.046)$ \\
\hline \multirow[t]{2}{*}{ log of firm age } & 0.023 & 0.024 & -0.050 & -0.026 & -0.039 & 0.020 & 0.019 & -0.051 & -0.025 & -0.039 \\
\hline & $(0.035)$ & $(0.030)$ & $(0.033)$ & $(0.033)$ & $(0.037)$ & $(0.034)$ & $(0.030)$ & $(0.034)$ & $(0.034)$ & $(0.038)$ \\
\hline \multirow[t]{2}{*}{$\%$ w. uni. degree } & 0.394 & $-0.984 * *$ & 0.844 & 0.341 & 0.688 & 0.276 & $-1.018^{* *}$ & 0.853 & 0.340 & 0.708 \\
\hline & $(0.536)$ & $(0.461)$ & $(0.513)$ & $(0.439)$ & $(0.571)$ & $(0.535)$ & $(0.446)$ & $(0.541)$ & $(0.465)$ & $(0.523)$ \\
\hline \multirow[t]{2}{*}{$\%$ w. uni. degree sq. } & -0.373 & $1.580^{* *}$ & -1.228 & -0.863 & $-1.818^{* *}$ & -0.171 & $1.610 * *$ & -1.223 & -0.855 & $-1.836^{* *}$ \\
\hline & $(0.758)$ & $(0.694)$ & $(0.813)$ & $(0.690)$ & $(0.735)$ & $(0.757)$ & $(0.689)$ & $(0.828)$ & $(0.695)$ & $(0.698)$ \\
\hline \multirow[t]{2}{*}{ No. of branches } & 0.088 & 0.079 & $0.117^{*}$ & 0.037 & -0.027 & $0.102 *$ & 0.077 & $0.116^{*}$ & 0.042 & -0.028 \\
\hline & $(0.073)$ & $(0.064)$ & $(0.069)$ & $(0.064)$ & $(0.076)$ & $(0.074)$ & $(0.067)$ & $(0.074)$ & $(0.065)$ & $(0.075)$ \\
\hline \multirow[t]{2}{*}{ No. of branches sq. } & $-0.063^{* *}$ & -0.014 & -0.028 & 0.009 & 0.011 & $-0.066^{* *}$ & -0.013 & -0.028 & 0.008 & 0.011 \\
\hline & $(0.023)$ & $(0.024)$ & $(0.023)$ & $(0.019)$ & $(0.025)$ & $(0.024)$ & $(0.025)$ & $(0.025)$ & $(0.019)$ & $(0.024)$ \\
\hline \multirow[t]{2}{*}{ Part of group } & -0.000 & -0.120 & $0.170^{*}$ & 0.087 & -0.042 & -0.002 & -0.109 & $0.169^{*}$ & 0.085 & -0.040 \\
\hline & $(0.092)$ & $(0.067)$ & $(0.085)$ & $(0.094)$ & $(0.093)$ & $(0.090)$ & $(0.064)$ & $(0.081)$ & $(0.095)$ & $(0.093)$ \\
\hline \multirow[t]{2}{*}{ Sells over internet } & -0.090 & 0.069 & -0.098 & -0.065 & -0.019 & -0.095 & 0.069 & -0.096 & -0.073 & -0.019 \\
\hline & $(0.072)$ & $(0.062)$ & $(0.073)$ & $(0.065)$ & $(0.077)$ & $(0.073)$ & $(0.056)$ & $(0.065)$ & $(0.067)$ & $(0.073)$ \\
\hline \multirow[t]{2}{*}{ Competition measure } & -0.017 & -0.005 & -0.039 & -0.013 & -0.009 & -0.018 & -0.007 & -0.039 & -0.013 & -0.009 \\
\hline & $(0.033)$ & $(0.028)$ & $(0.034)$ & $(0.032)$ & $(0.032)$ & $(0.038)$ & $(0.027)$ & $(0.029)$ & $(0.032)$ & $(0.031)$ \\
\hline \multirow[t]{2}{*}{ Family-owned } & 0.092 & 0.025 & 0.059 & 0.060 & $0.187^{* *}$ & 0.091 & 0.025 & 0.059 & 0.059 & $0.188^{* *}$ \\
\hline & $(0.078)$ & $(0.065)$ & $(0.072)$ & $(0.077)$ & $(0.081)$ & $(0.079)$ & $(0.065)$ & $(0.069)$ & $(0.075)$ & $(0.082)$ \\
\hline \multirow[t]{2}{*}{ Constant } & -0.410 & -0.363 & 0.146 & 0.260 & -0.200 & -0.406 & -0.018 & 0.145 & 0.245 & -0.200 \\
\hline & $(0.271)$ & $(0.285)$ & $(0.226)$ & $(0.215)$ & $(0.237)$ & $(0.279)$ & $(0.196)$ & $(0.225)$ & $(0.238)$ & $(0.259)$ \\
\hline R-squared & 0.008 & 0.007 & 0.022 & 0.005 & 0.029 & 0.015 & 0.002 & 0.022 & 0.009 & 0.029 \\
\hline $\mathrm{N}$ & 757 & 757 & 757 & 757 & 757 & 757 & 757 & 757 & 757 & 757 \\
\hline
\end{tabular}

$* \mathrm{p}<0.10,{ }^{* *} \mathrm{p}<0.05,{ }^{* * *} \mathrm{p}<0.01$.

All regressions include industry dummies

Bootstrap standard errors; Regressions only on sample of domestic firms 
Table 7: Foreign management capabilities and productive efficiency of retailers

\begin{tabular}{|c|c|c|c|c|c|c|c|c|}
\hline \multirow[b]{2}{*}{$\begin{array}{l}\text { Dependent } \\
\text { variable }\end{array}$} & \multicolumn{4}{|c|}{ OLS } & \multicolumn{4}{|c|}{ TOBIT } \\
\hline & $\begin{array}{l}\text { Within } \\
\text { Sector }\end{array}$ & $\begin{array}{l}\text { Within } \\
\text { Region }\end{array}$ & $\begin{array}{c}\text { Within } \\
\text { Sector/Region }\end{array}$ & $\begin{array}{c}\text { Across } \\
\text { Sector/Within } \\
\text { Region } \\
\end{array}$ & $\begin{array}{l}\text { Within } \\
\text { Sector }\end{array}$ & $\begin{array}{l}\text { Within } \\
\text { Region }\end{array}$ & $\begin{array}{c}\text { Within } \\
\text { Sector/Region }\end{array}$ & $\begin{array}{c}\text { Across } \\
\text { Sector/Within } \\
\text { Region }\end{array}$ \\
\hline & $7-1$ & $7-2$ & $7-3$ & $7-4$ & $7-5$ & $7-6$ & $7-7$ & $7-8$ \\
\hline \multirow[t]{2}{*}{ Own MC } & $0.024^{*}$ & $0.024^{*}$ & $0.025^{*}$ & $0.025^{* *}$ & $0.024^{*}$ & $0.025^{*}$ & $0.025^{*}$ & $0.025^{*}$ \\
\hline & $(0.013)$ & $(0.013)$ & $(0.013)$ & $(0.012)$ & $(0.012)$ & $(0.013)$ & $(0.014)$ & $(0.013)$ \\
\hline \multirow[t]{2}{*}{ Foreign MC } & -0.185 & 0.014 & -0.004 & 0.007 & -0.196 & 0.015 & -0.005 & 0.008 \\
\hline & $(0.172)$ & $(0.026)$ & $(0.026)$ & $(0.023)$ & $(0.174)$ & $(0.027)$ & $(0.028)$ & $(0.023)$ \\
\hline \multirow[t]{2}{*}{ log no. Employees } & $-0.037 * *$ & $-0.034^{* *}$ & $-0.033 * *$ & $-0.034 * *$ & $-0.037 * *$ & $-0.034 * *$ & $-0.034 * *$ & $-0.034 * *$ \\
\hline & $(0.016)$ & $(0.016)$ & $(0.016)$ & $(0.016)$ & $(0.015)$ & $(0.017)$ & $(0.016)$ & $(0.017)$ \\
\hline \multirow[t]{2}{*}{ log of firm age } & -0.015 & -0.015 & -0.015 & -0.015 & -0.015 & -0.014 & -0.015 & -0.015 \\
\hline & $(0.014)$ & $(0.014)$ & $(0.014)$ & $(0.014)$ & $(0.015)$ & $(0.014)$ & $(0.014)$ & $(0.015)$ \\
\hline \multirow[t]{2}{*}{ \% w. uni. Degree } & $0.219^{* *}$ & $0.223^{* *}$ & $0.221 * *$ & $0.223^{*}$ & $0.218^{* *} *$ & $0.222 * *$ & $0.220^{*}$ & $0.222 * *$ \\
\hline & $(0.103)$ & (0.108) & $(0.113)$ & $(0.115)$ & $(0.105)$ & $(0.109)$ & $(0.117)$ & $(0.102)$ \\
\hline \multirow[t]{2}{*}{ No. of branches } & $0.060^{* * *}$ & $0.056^{* * *}$ & $0.057 * * *$ & $0.057 * * *$ & $0.062^{* * *}$ & $0.058^{* * *}$ & $0.059 * * *$ & $0.058^{* * *}$ \\
\hline & $(0.016)$ & $(0.017)$ & $(0.017)$ & $(0.017)$ & $(0.016)$ & $(0.017)$ & $(0.017)$ & $(0.018)$ \\
\hline \multirow[t]{2}{*}{ Part of group } & 0.022 & 0.019 & 0.018 & 0.019 & 0.023 & 0.019 & 0.019 & 0.020 \\
\hline & $(0.037)$ & $(0.035)$ & $(0.035)$ & $(0.037)$ & $(0.037)$ & $(0.037)$ & $(0.035)$ & $(0.038)$ \\
\hline \multirow[t]{2}{*}{ Sells over internet } & 0.005 & 0.009 & 0.008 & 0.009 & 0.004 & 0.009 & 0.007 & 0.008 \\
\hline & $(0.023)$ & $(0.024)$ & $(0.023)$ & $(0.023)$ & $(0.024)$ & $(0.025)$ & $(0.025)$ & $(0.025)$ \\
\hline \multirow[t]{2}{*}{ Competition } & -0.000 & -0.000 & -0.000 & -0.000 & -0.001 & -0.001 & -0.001 & -0.001 \\
\hline & $(0.011)$ & $(0.013)$ & $(0.012)$ & $(0.011)$ & $(0.013)$ & $(0.012)$ & $(0.012)$ & $(0.012)$ \\
\hline \multirow[t]{2}{*}{ Family-owned } & -0.030 & -0.033 & -0.032 & -0.033 & -0.031 & -0.034 & -0.034 & -0.034 \\
\hline & $(0.030)$ & $(0.029)$ & $(0.026)$ & $(0.028)$ & $(0.029)$ & $(0.028)$ & $(0.030)$ & $(0.029)$ \\
\hline \multirow[t]{2}{*}{ Constant } & $0.318^{* *}$ & $0.276^{* *}$ & $0.279 * *$ & $0.277 * *$ & $0.321 * *$ & $0.277 * *$ & $0.280 * *$ & $0.277 * *$ \\
\hline & $(0.124)$ & $(0.127)$ & $(0.121)$ & $(0.122)$ & $(0.131)$ & $(0.126)$ & $(0.118)$ & $(0.124)$ \\
\hline R-squared & 0.102 & 0.095 & 0.094 & 0.095 & & & & \\
\hline $\mathrm{N}$ & 389 & 389 & 389 & 389 & 389 & 389 & 389 & 389 \\
\hline
\end{tabular}

Notes: ${ }^{*} \mathrm{p}<0.10,{ }^{* *} \mathrm{p}<0.05,{ }^{* * *} \mathrm{p}<0.01$; All regressions include industry dummies. Bootstrap standard errors in parentheses. Regressions only on sample of domestic firms. 
Table 8: Hypotheses and the Estimated Results

\begin{tabular}{llc}
\hline \hline Hypotheses & $\begin{array}{l}\text { Regression results } \\
\text { (Table-Column) }\end{array}$ & $\begin{array}{c}\text { Support (Y) or } \\
\text { not support (N) }\end{array}$ \\
\hline H1 (a) Within Sector & $5-2,5-4$ & Y (partial) \\
(b) Within Region & $5-7,5-9$ & N \\
(c) Within Sector/Region & $6-2,6-4$ & Y (partial) \\
(d) Across Sector/ Within Region & $6-7,6-9$ & $\mathrm{~N}$ \\
\hline H2 (a) Within Sector & $5-1,5-3,5-5$ & $\mathrm{Y}$ \\
(b) Within Region & $5-6,5-8,5-10$ & $\mathrm{Y}$ \\
(c) Within Sector/Region & $6-1,6-3,6-5$ & $\mathrm{Y}$ \\
(d) Across Sector/ Within Region & $6-6,6-8,6-10$ & $\mathrm{Y}$ \\
\hline H3 (a) Within Sector & $7-1,7-5$ & $\mathrm{Y}$ \\
(b) Within Region & $7-2,7-6$ & $\mathrm{Y}$ \\
(c) Within Sector/Region & $7-3,7-7$ & $\mathrm{Y}$ \\
(d) Across Sector/ Within Region & $7-4,7-8$ & $\mathrm{Y}$ \\
\hline \hline
\end{tabular}




\section{Appendix 1. Selected Survey questions}

We are interested in how capable your company is in the UK AT PRESENT and not in your company's future potential. Please answer as critically as you are able, recognising that all companies will have a profile of strengths and weaknesses in these areas.

1. How capable is your company at...

* Interviewees are asked to choose one of the following 6 grades. (answers such as "Don't know" and "Not relevant" are allowed and recorded.)

\begin{tabular}{|l|l|l|l|l|l|}
\hline NO & SMALL & MODERATE & QUITE A LOT & A GREAT DEAL & EXCELLENT \\
\hline
\end{tabular}

2. How many years have you been operating with at least a great deal of capability [include levels of 'a great deal' and 'excellent']?

\begin{tabular}{|c|}
\hline $\begin{array}{l}\text { Areas of management capabilities being asked } \\
\text { Human resource management }\end{array}$ \\
\hline 1. Attracting strong candidates for job vacancies? \\
\hline 2. Selecting good members of staff? \\
\hline 3. Retaining good staff? \\
\hline 4. Training staff in customer service and selling? \\
\hline 5. Training staff in product knowledge? \\
\hline 6. Developing staff to the best of their abilities? \\
\hline 7. Thoroughly appraising staff on a regular basis? \\
\hline 8. Identifying and promoting good people? \\
\hline 9. Managing 'poor performers'? \\
\hline Operations management \\
\hline 1. Ensuring staff rotas match the times customers are shopping? \\
\hline 2. Controlling waste? (e.g., damage and losses) \\
\hline 3. Ensuring stock is on the shelves and available at the right time? \\
\hline 4. Managing suppliers effectively? \\
\hline 5. Communicating with staff? \\
\hline 6. Listening to staff? \\
\hline 7. Empowering shop floor staff to take responsibility and make operational decisions? \\
\hline 8. Solving problems quickly on the shop floor? \\
\hline 9. Working in teams on the shop floor? \\
\hline 10. Working flexibly on the shop floor? \\
\hline 11. Using shop floor systems and processes that are clear and well-understood? \\
\hline Incentives \\
\hline 1. Providing a good reward package (in terms of both monetary and non-monetary rewards)? \\
\hline 2. Providing incentives that motivate staff to improve performance? \\
\hline 3. Praising and encouraging staff? \\
\hline 4. Providing clear targets for shop floor staff? \\
\hline 5. Routinely giving feedback to shop floor staff on their performance? \\
\hline Marketing \& leadership \\
\hline 1. Providing customers with high quality products and services? \\
\hline 2. Pricing products competitively? \\
\hline 3. Providing customers with value for money? \\
\hline 4. Having a strong brand/ image in the market place? \\
\hline 5. Gathering and listening to customer feedback? (eg through mystery shopping and exit surveys) \\
\hline 6. Advertising and promotions (including visual merchandising) \\
\hline 7. Implementing new initiatives to improve the business? \\
\hline 8. Providing leadership throughout the business? \\
\hline 9. Learning from competitors \\
\hline
\end{tabular}

Source: Celia et al. (2008) 


\section{Appendix 2. Factor model for the factor analysis of management capabilities}

More specifically, we estimate a standard factor model of the following form

$$
\tilde{y}_{j}^{k}=\beta_{0 j}^{k}+\beta_{1 j}^{k} M_{j}^{k}+u_{j}^{k}
$$

where $\tilde{y}_{j}^{k}$ denotes the observed values for the specific question relating to management capability $k$ with $k=1, \ldots, K$ denoting the different subcategories of a management capacity, $M$ is the specific latent management capability and $u$ is the error term. $\beta_{0 j}^{k}$ denotes the measure-specific intercept and $\beta_{1 j}^{k}$ are factor loadings. $\tilde{y}_{j}^{k}$ is computed as $\tilde{y}_{j}^{k}=y_{j}^{k}-\bar{y}^{k}$, where $y_{j}^{k}$ denotes the observed questionnaire response in form of a discrete rating ranging from zero to seven and $\bar{y}^{k}$ denotes the mean of all responses of firm $j$ within management category $k$. In estimating the model, we make a number of assumptions. First, the latent variable and the error term are uncorrelated, have mean zero and are normally distributed. Secondly, the error term is uncorrelated across firms. Thirdly, the relationship between the latent variable and the observed variables is linear. Fourthly, the factor variance is normalized to one. ${ }^{21}$

21 Since the questionnaire responses are ordered-categorical, we computed polychoric correlations to estimate (1), but found little differences between the results obtained from uncorrected correlations and therefore use unadjusted correlations. The corresponding results are available from the authors upon request. 


\section{Appendix 3.}

Under the assumption of convexity and monotonicity (i.e., free disposability of inputs and outputs) and allowing for variable returns to scale, with $y$ denoting output and $x$ input for $n$ firms in the sample, the production possibility set $T(x, y)$ can be written as (Banker, Charnes, and Cooper, 1984) [BCC]:

$$
T^{V R S}(x, y)=\left\{(x, y) \mid \sum_{i}^{n} \theta_{j} y_{j} \geq y, \sum_{i}^{n} \theta_{j} x_{j} \geq x, \sum_{i}^{n} \theta_{j}=1, \theta_{j} \geq 0 ; j=1, \ldots, n\right\}
$$

where $\theta \in[0,1]$. The set defined by (2) contains a convexity constraint $\sum_{i}^{n} \theta_{j}=1$. This restricts firms to convex combinations of input and output vectors.

A firm's efficiency is then defined as the firm's position relative to the frontier drawn by the production possibility set. In order to compute a measure of efficiency, the traditional measure of radial distance (Farrell, 1957) is used. The radial distance for the variable returns to scale case is obtained by maximizing a constrained optimization problem (Banker et al., 1984). This maximization problem can be transformed into a linear programming problem

$$
\begin{array}{ll}
e_{0}=\max \sum_{r}^{s} z_{r} y_{r 0}-u_{0} \\
\text { s.t. } \quad \sum_{i}^{m} u_{i} x_{i 0}=1 \\
\qquad \sum_{r}^{s} z_{r} y_{r j}+u_{0}-\sum_{i}^{m} u_{i} x_{i j} \leq 0 \quad \forall j \\
\quad z_{r}, u_{i}>0 \quad \forall r, i
\end{array}
$$

where $z_{r}, u_{i}$ and $u_{0}$ have been divided by $\left(\sum_{i}^{m} u_{i} x_{i 0}\right)$. In practice, however, commonly the corresponding dual problem is solved. 